\title{
NILAI - NILAI PENDIDIKAN KARAKTER DALAM KESENIAN REYOG PONOROGO
}

\author{
Nayif Al Rosidin \\ Institut Agama Islam Sunan Giri (INSURI) Ponorogo \\ rosidinal97@gmail.com
}

\section{Abstrak}

Reyog nowadays is merely seen by the public only as an art of entertainment and beauty, even though researchers believe that many values can be taken from the traditional art. As the generation of future who are obliged to maintain and preserve it, they must begin to see and understand this art from various perspectives. From the results of the study found that the values of character education in Reyog Ponorogo in terms of the symbolic meanings are Religiousity, symbols that show the value of religious characters one of which, Reyog is taken from Arabic (Riyyuq). Tolerance, Reyog gamelan which is based on pelog and slendro illustrates the difference situation. When it is played with a sense of tolerance, it can walk in harmony and go well together. Discipline and hard work, contained in the story of the figure Prabu Kelono Sewandono and his patih Pujangganong who have the spirit of discipline and hard work in running the government of the Kingdom of Bantarangin. Creativity, as Patih Pujangganong is creative as evidenced by the creation of Reyog art from his effort. The spirit of nationalism and love of the motherland, Reyog figures such as Warok, Pujangganong, Jathilan, etc who always acted faithfully to the kingdom and the king, showed a symbol of the spirit of nationalism and love of the motherland. Responsibility, Kelono Sewandono as a king has responsibility for the kingdom he dreams of. Thus, it can be concluded that the art of Reyog Ponorogo is very relevant to the objectives of Islamic Education.

Keywords: Values, Character Education, Reyog Art

Dewasa ini masyarakat hanya melihat Reyog, sebagai sebuah kesenian yang memiliki unsur hiburan dan keindahan. Peneliti meyakini banyak pesan yang dapat diambil dari Kesenian tersebut. Sebagai generasi penerus yang berkewajiban untuk tetap menjaga dan melestarikannya, harus mulai melihat dan memahami kesenian ini dari berbagai sudut pandang. Dari hasil penelitian ditemukan bahwa: (1) Nilai-Nilai Pendidikan Karakter dalam Kesenian Reyog Ponorogo di tinjau dari makna-makna simbolnya yaitu: Religius, simbol yang menunjukkan nilai karakter religius salah satunya, Reyog diambil dari bahasa Arab (Riyyuq). Toleransi, gamelan Reyog yang berlaras pelog dan slendro menggambarkan perbedaan jika disikapi dengan rasa toleransi, bisa berjalan penuh harmoni dan beriringan dengan baik. Disiplin dan Kerja keras, kisah tokoh Kelono Sewandono dan patihnya Pujangganong yang memiliki semangat disiplin dan kerja keras dalam menjalankan roda pemerintahan Kerajaan Bantarangin. Kreatif, Pujangganong menurut cerita rakyat adalah patih dari raja Kelono Sewandono, yang kreatif terbukti dengan terciptanya kesenian Reyog dari usahanya. Semangat Kebangsaan dan Cinta Tanah Air, tokoh-tokoh reyog seperti Warok, Pujangganong, Jathilan yang selalu bersikap dan bertindak setia pada kerajaan dan raja, menunjukan symbol semangat kebangsaan dan cinta tanah air yang tinggi. Tanggung Jawab, Kelono Sewandono sebagai seorang raja memiliki tanggung jawab terhadap kerajaan yang dipimpinya. (2) Nilai-Nilai Pendidikan Karakter dalam Kesenian Reyog Ponorogo di tinjau dari makna-makna simbolnya yaitu: Religius, Toleransi, Disiplin dan Kerja keras, Kreatif, Semangat Kebangsaan dan Cinta Tanah Air, Tanggung Jawab sangat relevan dengan Tujuan Pendidikan Islam.

Kata Kunci: Nilai, Pendidikan Karakter, Kesenian Reyog 


\section{Pendahuluan}

Membicarakan pendidikan sama halnya dengan membicarakan kehidupan yang tidak akan ada habisnya. Pendidikan dan kehidupan merupakan satu kesatuan yang akan selalu berjalan beriringan. Karena sesungguhnya pendidikan adalah bagian kehidupan itu sendiri. Pendidikan diartikan sebagai usaha sadar dan bertujuan untuk mengembangkan kualitas manusia. Lebih detail lagi pendidikan dapat diartikan sebagai usaha sadar yang dilakukan oleh keluarga, masyarakat dan pemerintah, melalui kegiatan bimbingan, pengajaran dan atau latihan, yang berlangsung di sekolah dan di luar sekolah sepanjang hayat, untuk mempersiapkan peserta didik agar dapat memainkan peranan dalam berbagai lingkungan hidup secara tepat di masa yang akan datang. ${ }^{1}$ Tujuan utama pendidikan adalah membentuk karakter peserta didik yang mampu mengemban misi untuk membuat lingkungannya lebih baik.

Berbicara tentang karakter ada banyak pengertian yang ditawarkan oleh para ahli di antaranya, Hermawan Kertajaya mengemukakan, karakter adalah "ciri khas" yang dimiliki oleh suatu benda atau individu. Ciri khas tersebut adalah "asli” dan mengakar pada kepribadian benda atau individu tersebut, dan merupakan "mesin" yang mendorong bagaimana seseorang bertindak, bersikap, berujar, dan merespon sesuatu. ${ }^{2}$ Jika dilihat dari kutipan pengertian tersebut, karakter mutlak diperlukan oleh seseorang yang merupakan pendorong utama untuk melakukan tindakan. Dengan kata lain sesorang yang memiliki karakter baik akan cenderung berbuat baik, begitupun sebaliknya. Pendidikanlah alat yang paling efektif dan efisien untuk mentransformasikan nilai-nilai karakter kepada peserta didik.

Dari paradigma ini muncul istilah pendidikan karakter yang dewasa ini menjadi isu sentral dalam dunia pendidikan di Indonesia khususnya. Pendidikan karakter merupakan keseluruhan proses pendidikan yang dialami peserta didik sebagai pengalaman pembentuk kepribadian melalui memahami dan mengalami sendiri nilai-nilai. ${ }^{3}$ Pengertian tersebut mengindikasikan bahwa kepribadian seseorang dapat dibentuk menjadi lebih baik melalui pendidikan karakter. Peneliti berkeyakinan bahwa transformasi nilai-nilai karakter tidak hanya

1 Redja Mudyaharjo, Pengantar Pendidikan Sebuah Studi Awal Tentang Dasar-dasar Pendidikan Pada Umumnya Dan Pendidikan Di Indonesia (Jakarta: Raja Grafindo Persada, 2001), 11.

2 M. Furqon Hidayatullah, Pendidikan Karakter Membangun Peradaban Bangsa (Surakarta: Yuma Pressindo, 2010), 12.

${ }^{3}$ Doni Koesoema A, Pendidikan Karakter, Strategi Mendidik Anak Di Zaman Global (Jakarta: Grasindo, 2007), 165. 
dilakukan melalui proses belajar mengajar di kelas. Berbagai media dapat dimanfaatkan dalam proses penanaman nilai-nilai karakter ini. Berkaca pada masa lalu proses penanaman nilai-nilai karakter banyak dilakukan melalui kebudayaan khususnya kesenian daerah.

Budaya diartikan sebagai keseluruhan sistem berpikir, nilai, moral, norma, dan keyakinan (belief) manusia yang dihasilkan masyarakat. ${ }^{4}$ Merujuk dari pengertian tersebut dapat diterjemahkan bahwa kebudayaan merupakan manifestasi dari nilai-nilai karakter sebuah masyarakat. Masyarakat membuat kebudayaan yang salah satunya dibingkai dalam sebuah kesenian adalah usaha untuk menjaga nilai-nilai luhur agar bisa terus diwariskan ke generasi selanjutnya. Salah satu contohnya adalah kesenian Reyog Ponorogo.

Kesenian Reyog dapat ditelusuri setidaknya hingga masa kebudayaan Hindu di Jawa Timur. Ada yang mengatakan bahwa kesenian ini erat kaitannya dengan legenda kerajaan Ponorogo (sekitar Abad ke-12). Keterkaitan kesenian Reyog dengan legenda kerajaan Ponorogo dan adanya tradisi Grebeg Suro dalam rangka pelestarian Reyog di Ponorogo membuat kesenian ini identik dengan daerah Ponorogo. ${ }^{5}$ Menurut Koentjoroningrat, Reyog merupakan tarian raksasa dari Ponorogo. Rombongan Reyog terdiri atas seorang penari topeng utama, empat penari kuda yang lazim disebut jatil, seseorang yang memerankan raksasa Reyog, ditambah dengan seseorang yang berperan memerangi raksasa tersebut, selain itu Reyog juga dilengkapi dengan seorang pelawak yang memakai topeng yang dikenal dengan pentulan dan lima atau enam orang pemain alat bunyi-bunyian yang terdiri dari kethuk, kendang, angklung, dan terompet. Dalam bukunya Maryani, diuraikan mengenai perlengkapan pertunjukan yang terdiri atas dadak merak dan barongan, topeng, dan jaran kepang. ${ }^{6}$ Kesenian Reyog Ponorogo dalam wujud sekarang ini adalah merupakan bentuk akhir dari suatu proses panjang yang di dalamnya terkandung nilai-nilai religius dan edukatif. Cerita legendaris "Klana Wuyung” hasil daya cipta Ki Ageng Mirah pada masa pemerintahan Batoro Katong. Cerita tersebut berkembang dikalangan masyarakat bahkan di dalam masyarakat diyakini betul-betul terjadi. ${ }^{7}$ Oleh karenanya menjadi sangat penting untuk menjaga dan melestarikan kesenian warisan leluhur ini.

Menurut peneliti ada beberapa hal yang menjadikan urgen kesenian ini untuk tetap dilestarikan dan dikembangkan yaitu: Pertama, dilihat dari segi historisnya Reyog merupakan

\footnotetext{
${ }^{4}$ Irhamni, Pengembangan Pendidikan Budaya Dan Karakter Bangsa (Ponorogo: Depag Ponorogo, 2011), 3 .

${ }^{5}$ Maryani, Metode Penelitian Kebudayaan (Jakarta: Bumi Aksara, 2005), 83.

${ }^{6}$ Ibid., 8.

${ }^{7}$ Pemerintah kabupaten Daerah Tingkat II ponorogo, Pedoman Dasar Kesenian Reog Ponorogo Dalam Pentas Budaya Bangsa (Ponorogo: PEMKAB Ponorogo, 1996), 26.
} 
salah satu budaya warisan leluhur yang tidak ternilai harganya. Kedua, dalam perjalanannya kesenian Reyog selalu menjadi media vital dalam proses penyebaran Islam, terutama di wilayah Ponorogo. Ketiga, di dalam kesenian Reyog Ponorogo terkandung nilai-nilai religius, edukatif yang merupakan perwujudan dari karakter masyarakat Ponorogo asli. Keempat, pada medio November 2007 Tari Reyog Ponorogo sempat menjadi bahan berita di Indonesia, saat Tari Barongan, yang persis bahkan sama dengan Reyog, menjadi bagian dari kampanye pariwisata Visit Malaysia 2007, "Malaysia Truly Asia". Yang paling menyinggung perasaan orang Ponorogo, sosok Singo Barong yang menjadi ikon Reyog pakai topeng Dadak Merak terkenalnya dengan tulisan "ReyogPonorogo"e yang seharusnya ada dimanapun Reyog dipentaskan. Malah tulisan Reyog Ponorogo itu diganti dengan satu kata: "Malaysia", dan diakui sebagai warisan masyarakat keturunan Jawa yang banyak terdapat di Batu Pahat, Johor dan Selangor, Malaysia. Hal ini memicu protes berbagai pihak Indonesia, termasuk seniman Reyog asal Ponorogo yang menyatakan bahwa hak cipta kesenian Reyog telah dicatatkan dengan Nomor: 026377 tertanggal 11 Februari 2004, dan dengan demikian diketahui oleh Menteri Hukum dan HAM Republik Indonesia. ${ }^{8}$

\section{Pembahasan}

\section{Nilai-Nilai Pendidikan Budaya dan Karakter Bangsa 1. Nilai}

Dalam kamus umum Bahasa Indonesia nilai diartikan sifat-sifat (hal-hal) yang penting atau berguna bagi kemanusiaan. ${ }^{9}$ Maksudnya kualitas yang memang membangkitkan respon penghargaan. Nilai itu praktis dan efektif dalam jiwa dan tindakan manusia dan melembaga secara objektif di dalam masyarakat. Adapun nilai dalam kamus besar bahasa Indonesia adalah: Harga (dalam taksiran harga), Harga uang (dibandingkan dengan harga uang yang lain), Angka kepandaian (biji, potensi), Banyak sedikitnya isi; kadar; mutu, Sifat-sifat (hal-hal) yang penting atau berguna bagi kemanusiaan, Sesuatu yang menyempurnakan manusia sesuai dengan hakikatnya: etika. $^{10}$

Sidi Gazalba mengartikan nilai sebagai sesuatu yang bersifat abstrak, ideal, dan bukan benda konkrit, bukan fakta, tidak hanya persoalan benar dan salah yang menuntut pembuktian empirik, melainkan penghayatan yang dikehendaki dan tidak dikehendaki. ${ }^{11}$

\footnotetext{
${ }^{8}$ http://id.wikipedia.org/wiki/Reyog_\%28Ponorogo\%29, Diakses, 5 Januari 2014.

${ }^{9}$ W.JS. Purwadarminta, Kamus Umum Bahasa Indonesia (Jakarta: Balai Pustaka, 1999), 677.

${ }^{10}$ Kamus Digital Kamus Besar Bahasa Indonesia.

${ }^{11}$ Chabib Thoha, Kapita Selekta Pendidikan Islam (Yogyakarta: Pustaka Pelajar,1996), 61.
} 
Menurut Chabib Thoha nilai merupakan sifat yang melekat pada sesuatu (sistem kepercayaan) yang telah berhubungan dengan subjek yang memberi arti (manusia yang meyakini). Pendapat lain yaitu Zakiyah Darajat via Athiyyatillah nilai adalah suatu perangkat keyakinan ataupun perasaan yang diyakini sebagai suatu identitas yang memberikan corak khusus kepada pola pemikiran, perasaan, keterkaitan maupun perilaku. ${ }^{12}$ Untuk keperluan suatu analisis ahli filsafat nilai membagi nilai ke dalam beberapa kelompok tergantung pada cara berpikir yang digunakannya. Tetapi pada dasarnya pembagian nilai dilakukan berdasarkan pertimbangan dua kriteria, yaitu nilai dalam bidang kehidupan manusia dan karakteristik jenis nilai secara hierarkis.

Kelompok nilai yang dimaksud adalah pertama, nilai teoritik yang melibatkan pertimbangan logis dan rasional dalam memikirkan dan membuktikan kebenaran sesuatu. Kedua, nilai ekonomi yang terkait dengan pertimbangan yang berkadar untung-rugi. Ketiga, nilai estetik yang menempatkan nilai tertingginya pada bentuk dan keharmonisan. Keempat, nilai sosial yang nilai tertingginya terdapat dalam nilai kasih sayang antar manusia. Kelima, nilai politik yang nilai tertingginya adalah kekuasaan. Keenam, nilai agama yang secara hakiki sebenarnya merupakan nilai yang memiliki dasar paling kuat dibandingkan dengan nilai-nilai sebelumnya. Nilai ini bersumber dari kebenaran tertinggi yang datangnya dari Tuhan. ${ }^{13}$ Dalam pendidikan Islam terdapat bermacam-macam nilai Islam yang mendukung dalam pelaksanaan pendidikan bahkan menjadi suatu rangkaian atau sistem di dalamnya. Nilai tersebut menjadi dasar pengembangan jiwa anak sehingga bisa memberi out put bagi pendidikan yang sesuai dengan harapan masyarakat luas. ${ }^{14}$ Berangkat dari dasar-dasar utama pendidikan Islam di atas, maka setiap aspek pendidikan Islam mengandung beberapa unsur pokok yang mengarah kepada pemahaman dan pengalaman doktrin Islam secara menyeluruh.

\section{Pendidikan}

Pendidikan sering diterjemahkan orang dengan pedagogi. Pada Yunani Kuno, seorang anak yang pergi dan pulang sekolah diantar seorang pelayan, pelayan tersebut biasa disebut paedagogos, penuntun anak. Disebut demikian karena di samping mengantar dan menjemput juga berfungsi sebagai pengasuh anak tersebut dalam rumah tangganya, sedangkan gurunya, yang mengajar, pada Yunani Kuno disebut governor. Governor sebagai

\footnotetext{
${ }^{12}$ Athiyyatillah, Nilai-nilai Pendidikan Islam dalam Ibadah Solat, skripsi, Fakultas Tarbiyah. UIN Malang. 2009, 126.

${ }^{13}$ Rohmat Mulyana, Mengartikulasikan Pendidikan Islam (Bandung: IKAPI, 2004), 33-36

${ }^{14}$ H. M. Arifin, Filsafat Pendidikan Islam (Jakarta: Bumi Aksara, 1987), 140.
} 
guru tidak mengajar secara klasikal seperti sekarang ini, melainkan secara individual. ${ }^{15}$ Dalam bahasa Romawi didapati istilah educate yang berarti membawa keluar (sesuatu yang abadi dalam). ${ }^{16}$ Dalam arti sederhana, pendidikan sering diartikan sebagai usaha manusia untuk membina kepribadiannya sesuai dengan nilai-nilai di dalam masyarakat dan kebudayaannya. ${ }^{17}$ Secara definitif pendidikan diartikan oleh para tokoh pendidikan, sebagai berikut:

a. John Dewey

Pendidikan adalah proses pembentukan kecakapan-kecakapan fundamental secara intelektual dan emosional ke arah alam dan sesama manusia.

b. Ki Hajar Dewantara

Pendidikan adalah menuntun segala kekuatan kodrat yang ada pada anak-anak agar mereka sebagai manusia dan sebagai anggota masyarakat dapat mencapai keselamatan dan kebahagiaan yang setinggi-tingginya.

c. Menurut UU No. 20 Tahun 2003

Pendidikan adalah usaha sadar yang terencana untuk mewujudkan suasana belajar dan proses pembelajaran agar peserta didik secara aktif mengembangkan potensi dirinya untuk memiliki kekuatan spiritual keagamaan, pengendalian diri, kepribadian, kecerdasan, akhlak mulia, serta keterampilan yang diperlukan dirinya, masyarakat bangsa dan negara. ${ }^{18}$

Berdasarkan definisi-definisi di atas, penulis berpendapat bahwa pendidikan adalah usaha sadar yang dilakukan oleh keluarga, masyarakat dan pemerintah, melalui kegiatan bimbingan, pengajar dan atau latihan, yang berlangsung di sekolah dan di luar sekolah sepanjang hayat, untuk mempersiapkan peserta didik agar dapat memainkan peranan dalam berbagai lingkungan hidup secara tepat dimasa yang akan datang.

\section{Konsep Tujuan Pendidikan Islam}

Pendidikan Islam seperti pendidikan pada umumnya yang berusaha membentuk pribadi manusia, harus melalui proses yang panjang dengan hasil yang tidak bisa diketahui dengan cepat. Oleh karena itu dalam pendidikan pembentukan tersebut diperlukan suatu perhitungan yang matang dan hati-hati berdasarkan pandangan dan rumusan-rumusan yang jelas dan tepat. Sehubungan dengan hal tersebut pendidikan Islam harus memahami dan menyadari betul apa sebenarnya tujuan yang ingin dicapai dalam proses pendidikan.

\footnotetext{
${ }^{15}$ Noeng Muhadjir, Ilmu Pendidikan dan Perubahan Sosial (Yogyakarta: Rake Sarasin, 2000), 20.

${ }^{16}$ Mukhlison Effendi, Ilmu Pendidikan (Ponorogo: STAIN Ponorogo Press, 2008), 1.

${ }^{17}$ Hasbullah, Dasar-Dasar Ilmu Pendidikan (Jakarta: Raja Grafindo Persada, 1999), 1.

${ }^{18}$ Ibid.
} 
Tujuan pendidikan merupakan masalah sentral dalam pendidikan. Sebab tanpa perumusan yang jelas tentang tujuan tersebut, perbuatan menjadi acak-acakan, tanpa arah, bahkan bisa sesat atau salah. Oleh karena itu perumusan tujuan dengan tegas dan jelas menjadi inti dari seluruh pemikiran pedagogis dan perenungan filosofis. ${ }^{19}$

Tujuan pendidikan Islam dirumuskan dari nilai-nilai filosofis yang kerangka dasarnya termuat dalam sebuah karya pendidikan Islam. Seperti halnya dasar pendidikannya maka tujuan dari pendidikan Islam juga identik dengan tujuan Islam itu sendiri. ${ }^{20}$ Kalau melihat kembali pengertian pendidikan Islam akan terlihat dengan jelas sesuatu yang diharapkan terwujud setelah orang mengalami pendidikan Islam secara keseluruhan, yaitu kepribadian seseorang yang membuatnya menjadi insan kamil dengan pola takwa.

Rumusan tujuan itu pada hakikatnya merupakan rumusan filosofis atau pemikiran yang mendalam tentang pendidikan. Seseorang baru dapat merumuskan tujuan itu jika ia memahami secara benar filsafat yang mendasarinya. Rumusan tujuan ini yang kemudian akan menentukan aspek-aspek yang ada dalam sebuah pendidikan. ${ }^{21}$

Dalam hal ini peneliti menggunakan konsep tujuan pendidikan Islam al-Ghazali sebagai dasar teori. Jika pendidikan bisa dipandang sebagai aplikasi pemikiran filsafati dan seorang filosuf bergerak selaras dengan jalan dan dasar pemikirannya, maka al-Ghazali dengan sistem pemikirannya sejalan dengan dasar pemikiran filsafatnya yang mengarah kepada tujuan yang jelas. Dengan demikian sistem pendidikan haruslah mempunyai filsafat yang mengarahkan kepada tujuan tertentu. ${ }^{22}$

Menurut Al-Ghazali, dalam prosesnya pendidikan haruslah mengarah kepada pendekatan diri kepada Allah Swt dan kesempurnaan insan, mengarahkan manusia untuk mencapai tujuan hidupnya itu yaitu bahagia dunia akhirat. Oleh karena itu, tujuan dari pendidikan yang dirumuskan oleh beliau yakni pendidikan merupakan pendekatan kepada Allah Swt. Allah berfirman: "Dan aku tidak menciptakan jin dan manusia melainkan supaya mereka mengabdi kepada-Ku". (Q.S. ad Dzariyat: 56). ${ }^{23}$

Orang dapat mendekatkan diri kepada Allah Swt hanya setelah memperoleh ilmu pengetahuan. Ilmu pengetahuan itu sendiri tidak akan didapatkan oleh manusia tanpa melalui proses pengajaran. Selanjutnya, dari kata-kata tersebut dapat dipahami bahwa

${ }^{19}$ Ramayulis, Ilmu Pendidikan Islam cet VII. (Jakarta: Kalam Mulia, 2002), 132-133.

${ }^{20}$ Jalaludin, Teologi Pendidikan.cet III. (Jakarta: PT Raja Grafindo Persada, 2003), 91.

${ }^{21}$ Abuddin Nata, Pemikiran Para Tokoh Pendidikan Islam (Jakarta: PT Raja Grafindo Persada, 2000), 86.

${ }^{22}$ Abidin Ibnu Rusn, Pemikiran Al-Ghazali tentang Pendidikan (Yogyakarta: Pustaka Pelajar, 1998), 56-

59.

${ }^{23}$ Depag RI, Al-Qur'an dan Terjemahannya, 417. 
menurut Al-Ghazali, tujuan pendidikan dapat dibagi menjadi dua yakni tujuan jangka panjang dan tujuan jangka pendek. ${ }^{24}$

Pertama, tujuan jangka panjang ialah pendekatan diri kepada Allah Swt. Pendidikan dalam prosesnya harus mengarahkan manusia menuju pengenalan dan kemudian pendekatan diri kepada Tuhan pencipta alam. Lanjutnya manusia dapat mendekatkan diri kepada Allah Swt adalah dengan melaksanakan ibadah wajib dan ibadah sunnah. ${ }^{25}$

Di samping harus melaksanakan ibadah wajib dan sunnah untuk mendekatkan diri kepada Allah Swt manusia harus senantiasa mengkaji ilmu-ilmu fardlu 'ain. Alasannya, di sanalah terdapat hidayah al-din, hidayah agama yang termuat dalam ilmu syari'ah. Sementara orang yang hanya menekuni ilmu fardlu kifayat sehingga memperoleh profesiprofesi tertentu dan akhirnya mampu melaksanakan tugas-tugas keduniaan dengan hasil yang semaksimal dan seoptimal mungkin tetapi tidak disertai hidayah al-din, maka orang tersebut tidak semakin dekat kepada Allah Swt bahkan semakin jauh dari-Nya. ${ }^{26}$

Orang-orang seperti ini tidak dapat melaksanakan tugas-tugas ukhrawi dengan baik, ia lebih cinta dunia dan karena itu dia lupa akhirat. Akibatnya dia tidak bisa mencapai tujuan hidupnya yakni bahagia di akhirat karena tidak melaksanakan tugas-tugas akhirat. Tentu saja untuk mewujudkan hal itu bukanlah sistem pendidikan sekuler yang memisahkan ilmuilmu keduniaan dari nilai-nilai kebenaran dan sikap religious, dan juga bukan merupakan sistem Islam tradisional akan tetapi memadukan keduanya secara integral. Dengan sistem inilah yang mampu membentuk manusia yang dapat melaksanakan tugas-tugas kekhalifahan. ${ }^{27}$

Kedua, tujuan jangka pendek ialah diraihnya profesi manusia sesuai dengan bakat dan kemampuannya. Syarat untuk mencapai tujuan itu, manusia mengembangkan ilmu pengetahuan baik termasuk fardlu 'ain maupun fardlu kiyafat. Oleh karena itu, pengiriman para pelajar dan mahasiswa ke negara lain untuk memperoleh spesifikasi ilmu-ilmu kealaman demi kemajuan Negara tersebut menurut konsep ini sangat tepat sekali. Sebagai implikasi dari konsep tersebut, umat Islam dalam menuntut ilmu untuk menegakkan urusan keduniaan atau melaksanakan tugas-tugas keakhiratan tidak harus dan tidak terbatas kepada Negara-negara Islam, akan tetapi boleh dimana saja bahkan di Negara anti Islam tersebut. ${ }^{28}$

\footnotetext{
${ }^{24}$ Ibnu Rusn, Pemikiran Al-Ghazali tentang Pendidikan, 56-61.

${ }^{25}$ Ibid,. 59-61.

${ }^{26}$ Ibid., 59-61.

${ }^{27}$ Ibid., 59-61.

${ }^{28}$ Ibid., 59-61.
} 
Dengan menguasai ilmu-ilmu fardlu kifayah dan selanjutnya menguasai profesi-profesi tertentu, manusia dapat melaksanakan tugas-tugas keduniaan dan dapat bekerja sebaikbaiknya. Tetapi jika kurang menguasai bahkan tidak kenal sama sekali ilmu-ilmu itu, lalu kita menyerahkan kepada orang yang bukan ahlinya, maka kejadiannya akan menghancurkannya. ${ }^{29}$

Berhubungan dengan tujuan jangka pendek, yakni terwujudnya kemampuan manusia melaksanakan tugas-tugas keduniaan dengan baik, al-Ghazali menyinggung masalah kepopularitasan, kedudukan, kemegahan, pangkat dan kemuliaan dunia secara murni bukan merupakan tujuan dasar dari seseorang yang melibatkan dirinya ke dalam dunia pendidikan. Seseorang yang sebagai pemberi atau pun pencari ilmu ${ }^{30}$ mereka semua akan memperoleh derajat dan segala macam kemuliaan manakala ia benar-benar mempunyai motivasi hendak meningkatkan kualitas dirinya melalui ilmu pengetahuan dan ilmu pengetahuan itu untuk diamalkan. Karena itulah, al-Ghazali menegaskan bahwa langkah awal seseorang dalam belajar adalah mensucikan jiwa dari kerendahan budi dan sifat-sifat tercela, dan motivasi pertama adalah untuk menghidupkan syari'at dan misi Rasulullah, bukan untuk mencari kemegahan duniawi.

Dari dua tujuan di atas maka dapat kita ketahui secara bersama, bahwasannya tujuan pendidikan yang diinginkan oleh al-Ghazali adalah untuk mendekatkan diri kepada Allah Swt, menggali dan mengembangkan potensi manusia, mewujudkan profesionalisasi manusia untuk mengemban tugas keduniaan dengan sebaik-baiknya, membentuk manusia yang berakhlak mulia dan suci jiwanya dari kerendahan budi ataupun sifat tercela dan juga untuk mengembangkan sifat-sifat manusia yang utama sehingga menjadi manusia yang manusiawi. Peneliti berpendapat tujuan akhir dari pendidikan yang dirumuskan oleh alGhazali adalah untuk tercapainya kesempurnaan insan yang bermuara pada pendekatan diri kepada Allah Swt dan kesempurnaan insan yang bermuara pada kebahagiaan dunia akhirat. Oleh karena itu, ia mencita-citakan mengajarkan manusia agar sampai pada sasaran-sasaran yang merupakan tujuan akhir dan maksud pendidikan itu, hal ini tampak bernuansa religious dan moral serta tanpa mengabaikan masalah duniawi.

\section{Pendidikan Akhlak}

Pendidikan akhlak merupakan suatu proses mendidik, memelihara, membentuk dan memberikan latihan mengenai akhlak dan kecerdasan berpikir baik yang bersifat formal

\footnotetext{
${ }^{29}$ Ibid., 59-61.

${ }^{30}$ Ibid., 59-61.
} 
maupun informal yang didasarkan pada ajaran-ajaran Islam. Pada sistem pendidikan Islam ini khusus memberikan pendidikan tentang akhlak dan moral yang bagaimana yang seharusnya dimiliki oleh seorang muslim agar dapat mencerminkan kepribadian seorang muslim. ${ }^{31}$

Islam memandang bahwa pendidikan akhlak sangatlah penting dalam kehidupan seharihari, bahkan Islam menegaskan akhlak merupakan misinya yang paling utama. Rasulullah Saw. banyak berdoa kepada Allah Swt agar dirinya dihiasi dengan akhlak dan perangai yang mulia. $^{32}$

Menurut Prof. Dr. Abdullah Nashih Ulwan: Pendidikan Akhlak (moral) adalah pendidikan mengenai dasar-dasar moral dan keutamaan perangai, tabiat yang harus dimiliki dan dijadikan kebiasaan oleh anak sejak masa anak-anak sampai ia menjadi seorang mukallaf, pemuda yang mengarungi lautan kehidupan.

Pendidikan akhlak adalah suatu pendidikan yang di dalamnya terkandung nilai-nilai budi pekerti, baik yang bersumber dari ajaran agama maupun dari kebudayaan manusia. Budi pekerti mencakup pengertian watak, sikap, sifat, moral yang tercermin dalam tingkah laku baik dan buruk yang terukur oleh norma-norma sopan santun, tata krama dan adat istiadat, sedangkan akhlak diukur dengan menggunakan norma-norma agama. ${ }^{33}$ Dan contoh budi pekerti itu telah ada pada di Rasulullah Saw, seperti firman Allah "Sesungguhnya telah ada pada (diri) Rasulullah itu suri teladan yang baik bagimu (yaitu) bagi orang yang mengharap (rahmat) Allah dan (kedatangan) hari kiamat dan Dia banyak menyebut Allah". (Q.S. Al Ahzab: 21) $)^{34}$

Pendidikan akhlak dapat diartikan usaha sungguh-sungguh untuk mengubah akhlak buruk menjadi akhlak yang baik. Dapat diartikan bahwa akhlak itu dinamis, tidak statis. Terus mengarah kepada kemajuan dari yang tidak baik menjadi baik.56 Firman Allah Swt: “Dan Sesungguhnya kamu benar-benar berbudi pekerti yang agung”. (Q.S. Al Qalam: 4) ${ }^{35}$ Sedangkan menurut penulis adalah salah satu usaha yang dilakukan dengan kesadaran diri untuk membentuk pribadi seseorang yang harus dimiliki dan dijadikan kebiasaan yang baik dan terarah menurut akal ataupun syara' oleh manusia sejak lahir sampai meninggal dunia.

${ }^{31}$ Fadlil Yuni Ainusysyam, Pendidikan Akhlak (Jakarta: PT Imtima, Cet. III, 2009), 39

${ }^{32}$ Said Hawwa, Tazkiyatun Nafs Intisari Ihya Ulumuddin (terj. Tim Kuwais), (Jakarta : Darus Salam, 2005), 462

${ }_{33}$ Ahmad, Implementasi Akhlak Qur'ani (Bandung : PT Telekomunikasi Indonesia , 2002), 34

${ }^{34}$ Depag RI, al-Qur'an dan Terjemahannya, 336

${ }^{35}$ Depag RI, al-Qur'an dan Terjemahannya, 451 


\section{Budaya}

Budaya adalah bentuk jamak dari kata budi dan daya yang berarti cinta, karsa, rasa. Kata budaya sebenarnya dari bahasa Sansekerta budhayah yaitu bentuk jamak kata buddhi yang berarti budi atau akal. Dalam bahasa Inggris, kata budaya berasal dari kata culture, dalam bahasa Latin berasal dari kata colera. Colera berarti mengolah, mengerjakan, menyuburkan, mengembangkan tanah (bertani). Kemudian pengertian ini berkembang dalam arti culture, yaitu sebagai daya dan aktivitas manusia untuk mengolah dan mengubah alam. Kebudayaan atau budaya menyangkut keseluruhan aspek kehidupan manusia baik material maupun non material. ${ }^{36}$ Budaya diartikan sebagai keseluruhan sistem berpikir, nilai, moral, norma, dan keyakinan (belief) manusia yang dihasilkan masyarakat. Sistem berpikir, nilai, moral, norma, dan keyakinan itu adalah hasil dari interaksi manusia dengan sesamanya dan lingkungan alamnya. Sistem berpikir, nilai, moral, norma dan keyakinan itu digunakan dalam kehidupan manusia dan menghasilkan sistem sosial, sistem ekonomi, sistem kepercayaan, sistem pengetahuan, teknologi, seni, dan sebagainya. Manusia sebagai makhluk sosial menjadi penghasil sistem berpikir, nilai, moral, norma, dan keyakinan.

\section{a. Wujud Kebudayaan}

Beberapa ilmuwan seperti Talcott Parson (Sosiolog) dan Al Kroeber (Antropolog) menganjurkan untuk membedakan wujud kebudayaan secara tajam sebagai suatu rangkaian dan aktivitas manusia yang berpola. Demikian pula J.J Honigman dalam bukunya The World of Man (1959) membagi budaya dalam tiga wujud yaitu: Ideas, activities, and artifact. ${ }^{37}$ Sejalan dengan pikiran para ahli tersebut, Koentjaraningrat mengemukakan bahwa kebudayaan dibagi menjadi tiga wujud yaitu:

Pertama, wujud sebagai suatu yang kompleks dari ide-ide, gagasan, nilai-nilai, norma-norma dan peraturan. Wujud tersebut menunjukan wujud ide dari kebudayaan, sifatnya abstrak, tak dapat diraba, dipegang ataupun difoto dan tempatnya ada di alam pikiran warga masyarakat dimana kebudayaan yang bersangkutan hidup. Kebudayaan ideal ini disebut juga tata kelakuan, hal ini menujukan bahwa budaya ideal mempunyai fungsi mengatur, mengendalikan dan memberi arah pada tindakan, kelakuan, dan perbuatan manusia dalam masyarakat sebagai sopan santun. Kebudayaan ideal ini dapat disebut sebagai adat atau adat istiadat yang sekarang banyak tersimpan dalam arsip, buku-

\footnotetext{
${ }^{36}$ Elly M. Setiadi, Ilmu Sosial dan Budaya Dasar (Jakarta: Kencana, 2006), 27-33

${ }^{37}$ Ibid., 28-30 60 Ibid, 28-30
} 
buku, tape, dan komputer. Kesimpulanya, budaya ideal ini adalah perwujudan dan kebudayaan yang bersifat abstrak. ${ }^{38}$

Kedua, wujud kebudayaan sebagai suatu kompleks aktivitas serta tindakan berpola dari manusia dalam masyarakat. Wujud tersebut dinamakan sistem sosial, karena menyangkut tindakan dan kelakuan yang berpola dari manusia itu sendiri. Wujud ini bisa diobservasi, difoto dan didokumentasikan karena dalam sistem sosial ini terdapat manusia yang saling berinteraksi satu dengan yang lainya. Kesimpulannya sistem sosial ini, perwujudan kebudayaan yang konkret dalam bentuk perilaku dan bahasa. ${ }^{39}$

Ketiga, wujud kebudayaan sebagai benda-benda hasil karya manusia. Wujud kebudayaan ini disebut juga kebudayaan fisik. Dimana wujud budaya ini hampir seluruhnya merupakan hasil fisik (aktivitas perbuatan, dan karya semua manusia dalam masyarakat). Sifatnya paling konkret dan berupa benda-benda atau hal-hal yang dapat diraba, dilihat dan difoto yang berwujud besar ataupun kecil. Contohnya: candi Borobudur (besar), kain batik, dan kancing baju (kecil). Kesimpulannya, kebudayaan fisik ini merupakan perwujudan kebudayaan yang bersifat konkret dalam bentuk materi/artefak. ${ }^{40}$

Dalam kenyataan kehidupan bermasyarakat, wujud kebudayaan yang satu dan lainya tidak bisa dipisahkan. Sebagai contoh: wujud kebudayaan gagasan (ideas) mengatur dan memberi arah kepada tindakan (activities) dan karya (artifact). ${ }^{41}$

\section{b. Unsur-Unsur Kebudayaan dalam Masyarakat Ada Tujuh sebagai Berikut:42}

1) Teknologi atau Sistem Peralatan

Komponen atau unsur utama kebudayaan antara lain peralatan dan perlengkapan (teknologi). Teknologi menyangkut cara-cara atau teknik memproduksi, memakai serta memelihara segala perlengkapan dan peralatan. Teknologi muncul dalam cara-cara manusia mengorganisasikan masyarakat, mengekspresikan rasa keindahan atau memproduksi hasil-hasil kesenian.

2) Sistem Mata Pencahariaan hidup

Perhatian para ilmuwan pada sistem mata pencaharian ini terfokus pada masalah-masalah mata pencahariaan tradisional saja, di antaranya berburu, meramu, beternak, bercocok tanam, dan menangkap ikan.

\footnotetext{
${ }^{38}$ Ibid.

${ }^{39}$ Ibid., 28-30 62 Ibid, 28-30 63 Ibid, 28-30

${ }^{40}$ Ibid., 28-30

${ }^{41}$ Ibid., 28-30

${ }^{42}$ Ramdani Wahyu, Ilmu Budaya Dasar (Bandung: Pustaka Setia, 2008), 105-112
} 
3) Organisasi sosial

Organisasi sosial adalah perkumpulan sosial yang dibentuk oleh masyarakat, baik yang berbadan hukum maupun yang tidak berbadan hukum, yang berfungsi sebagai sarana partisipasi masyarakat dalam pembangunan bangsa dan negara serta untuk mencapai tujuan tertentu yang tidak dapat dicapai seorang diri.

4) Bahasa

Bahasa adalah alat atau perwujudan budaya yang digunakan manusia untuk saling berkomunikasi atau hubungan, baik melalui lisan, tulisan, atau gerakan (bahasa isyarat), dengan tujuan menyampaikan maksud hati atau kemauan kepada orang lain.

\section{5) Sistem Kepercayaaan}

Ada kalanya pengetahuan, pemahaman, dan daya tahan fisik manusia dalam menguasai dan mengungkap rahasia-rahasia alam sangat terbatas. Secara bersamaan, muncul keyakinan akan adanya penguasa tertingi dari sistem jagad raya ini, yang mengendalikan manusia sebagai salah satu bagian jagad raya. Sehubungan dari itu baik secara individual maupun bermasyarakat, manusia tidak dapat dilepaskan dari religi atau sistem kepercayaan kepada penguasa alam semesta. Agama dan sistem kepercayaan lainnya sering terintegrasi dengan kebudayaan. Agama adalah sebuah unsur kebudayaan yang penting dalam sejarah umat manusia.

6) Sistem Ilmu dan Pengetahuan

Secara sederhana, pengetahuan adalah segala sesuatu yang diketahui manusia tentang benda, sifat, keadaan dan harapan-harapan. Pengetahuan dimiliki oleh semua suku bangsa di dunia. Mereka memperoleh pengetahuan melalui pengalaman, intuisi, wahyu, dan berpikir menurut logika, atau percobaan-percoban yang bersifat empiris (trial and error). Sistem pengetahuan tersebut dikelompokkan menjadi pengetahuan tentang alam, pengetahuan 37 tentang tumbuh-tumbuhan dan hewan disekitarnya, pengetahuan tentang tubuh manusia, pengetahuan tentang sifat dan tingkah laku sesama manusia, pengetahuan tentang ruang dan waktu.

7) Kesenian

Kesenian mengacu pada nilai keindahan (estetika) yang berasal dari ekspresi hasrat manusia akan keindahan yang dinikmati dengan mata ataupun telinga. Sebagai makhluk yang mempunyai cita rasa tinggi, manusia menghasilkan berbagai corak kesenian, mulai dari yang sederhana hingga perwujudan kesenian yang kompleks. Seni pada mulanya adalah proses dari manusia, dan oleh karena itu 
merupakan sinonim dari ilmu. Dewasa ini, seni bisa dilihat dalam intisari ekspresi dari kreatifitas manusia.

Seni sangat sulit untuk dijelaskan dan juga sulit dinilai, bahwa masingmasing individu artis memilih sendiri peraturan dan parameter yang menuntunnya atau kerjanya, masih bisa dikatakan bahwa seni adalah proses dan produk dari memilih medium, dan suatu set peraturan untuk penggunaan medium itu, dan suatu set nilai-nilai yang menentukan apa yang pantas dikirimkan dengan ekspresi lewat medium itu, untuk menyampaikan baik kepercayaan, gagasan, sensasi, atau perasaan dengan cara seefektif mungkin untuk medium itu. Sekalipun demikian, banyak seniman mendapat pengaruh dari orang lain masa lalu, dan juga beberapa garis pedoman sudah muncul untuk mengungkap gagasan tertentu lewat simbolisme 38 dan bentuk (seperti bakung yang bermaksud kematian dan mawar merah yang bermaksud cinta).

\section{Karakter Bangsa}

Kata karakter berasal dari bahasa yunani yang berarti "to mark" (menandai) dan memfokuskan pada bagaimana mengaplikasikan nilai kebaikan dalam bentuk tindakan atau tingkah laku. ${ }^{43}$ Menurut Kamus Besar Bahasa Indonesia, karakter diartikan sebagai sifatsifat kejiwaan, akhlak, atau budi pekerti yang membedakan seseorang dengan orang yang lain, karakter juga bisa diartikan sebagai tabiat, yaitu perangai atau perbuatan yang selalu dilakukan atau kebiasaan, karakter juga diartikan watak, yaitu sifat batin manusia yang mempengaruhi segenap pikiran dan tingkah laku atau kepribadian. ${ }^{44}$ Karakter adalah sikap pribadi yang stabil hasil proses konsolidasi secara progresif dan dinamis, integrasi pernyataan dan tindakan. ${ }^{45}$

Hermawan Kertajaya mengemukakan bahwa, karakter adalah "ciri khas" yang dimiliki oleh suatu benda atau individu. Ciri khas tersebut adalah "asli" dan mengakar pada kepribadian benda atau individu tersebut, dan merupakan "mesin" yang mendorong bagaimana seorang bertindak, bersikap, berujar dan merespon sesuatu. ${ }^{46}$ Karakter (character) mengacu pada serangkaian sikap (attitudes), prilaku (behaviors), motivasi (motivations), keterampilan (skill). Karakter meliputi sikap seperti keinginan melakukan hal

${ }^{43}$ M. Furqan Hidayatulloh, Pendidikan Karakter Membangun Peradaban Bangsa, 12.

${ }^{44}$ Najib Sulhan, Pendidikan Berbasis Karakter, Sinergi Antara Sekolah dan Rumah dalam Membentuk Karakter Anak (Surabaya: Jepe Press, 2010), 1.

45 Yahya Khan, Pendidikan Karakter Berbasis Potensi Diri, Mendongkrak Kualitas Pendidikan (Yogyakarta: Pelangi Publishing, 2010), 1.

${ }^{46}$ M. Furqan Hidayatulloh, Pendidikan Karakter Membangun Peradaban Bangsa, 13. 
yang terbaik, kapasitas intelektual seperti berfikir kritis dan alasan moral, perilaku seperti jujur dan bertanggung jawab, mempertahankan prinsip-prinsip moral dalam situasi penuh ketidakadilan, kecakapan interpresional dan emosional memungkinkan seseorang berinteraksi secara efektif dalam berbagai keadaan, dan komitmen untuk berkontribusi dengan komunitas masyarakatnya. Karakteristik adalah realisasi perkembangan positif sebagai individu (intelektual, sosial, emosional dan etika). Individu yang berkarakter baik adalah seseorang yang berusaha melakukan hal yang terbaik. ${ }^{47}$

Karakter adalah watak, tabiat, akhlak, atau kepribadian seseorang yang terbentuk dari hasil internalisasi berbagai kebajikan (virtues) yang diyakini dan digunakan sebagai landasan untuk cara pandang, berpikir, bersikap, dan bertindak. Kebajikan terdiri atas sejumlah nilai, moral, dan norma, seperti jujur, berani bertindak, dapat dipercaya, dan hormat kepada orang lain. Interaksi seseorang dengan orang lain menumbuhkan karakter masyarakat dan karakter bangsa. Oleh karena itu, pengembangan karakter bangsa hanya dapat dilakukan melalui pengembangan karakter individu seseorang. Akan tetapi, karena manusia hidup dalam lingkungan sosial dan pengenalan dan kemudian pendekatan diri kepada Tuhan pencipta alam. Lanjutnya manusia dapat mendekatkan diri kepada Allah Swt adalah dengan melaksanakan ibadah wajib dan ibadah sunnah. ${ }^{48}$

Di samping harus melaksanakan ibadah wajib dan sunnah untuk mendekatkan diri kepada Allah Swt manusia harus senantiasa mengkaji ilmu-ilmu fardlu 'ain. Alasannya, di sanalah terdapat hidayah al-din, hidayah agama yang termuat dalam ilmu syariah. Sementara orang yang hanya menekuni ilmu fardlu kifayat sehingga memperoleh profesiprofesi tertentu dan akhirnya mampu melaksanakan tugas-tugas keduniaan dengan hasil yang semaksimal dan seoptimal mungkin tetapi tidak disertai hidayah al-din, maka orang tersebut tidak semakin dekat kepada Allah Swt bahkan semakin jauh dari-Nya.

Orang-orang seperti ini tidak dapat melaksanakan tugas-tugas ukhrawi dengan baik, ia lebih cinta dunia dan karena itu dia lupa akhirat. Akibatnya dia tidak bisa mencapai tujuan hidupnya yakni bahagia di akhirat karena tidak melaksanakan tugas-tugas akhirat. Tentu saja untuk mewujudkan hal itu bukanlah sistem pendidikan sekuler yang memisahkan ilmuilmu keduniaan dari nilai-nilai kebenaran dan sikap religious, dan juga bukan merupakan sistem Islam tradisional akan tetapi memadukan keduanya secara integral. Dengan sistem inilah yang mampu membentuk manusia yang dapat melaksanakan tugas-tugas

${ }^{47}$ Arismantoro, Tinjauan Berbagai Aspek "Character Building” Bagaimana Mendidik Anak Berkarakter (Yogyakarta: Tiara Wacana, 2008), 27.

${ }^{48}$ Ibid. 
kekhalifahan. Kedua, tujuan jangka pendek ialah diraihnya profesi manusia sesuai dengan bakat dan kemampuannya. Syarat untuk mencapai tujuan itu, manusia mengembangkan ilmu pengetahuan baik termasuk fardlu'ain maupun fardlu kifayat. Oleh karena itu, pengiriman para pelajar dan mahasiswa kenegara lain untuk memperoleh spesifikasi ilmuilmu kealaman demi kemajuan Negara tersebut menurut konsep ini sangat tepat sekali. Sebagai implikasi dari konsep tersebut, umat Islam dalam menuntut ilmu untuk menegakkan urusan keduniaan atau melaksanakan tugas-tugas keakhiratan tidak harus dan tidak terbatas kepada Negara-negara Islam, akan tetapi boleh dimana saja bahkan di Negara anti Islam tersebut. $^{49}$

\section{Fungsi Pendidikan Budaya dan Karakter Bangsa}

a. Pengembangan: pengembangan potensi peserta didik untuk menjadi pribadi yang berperilaku baik. Ini bagi peserta didik yang telah memiliki sikap dan perilaku yang mencerminkan budaya dan karakter bangsa.

b. Perbaikan: memperkuat kiprah pendidikan nasional untuk bertanggung jawab dalam pengembangan potensi peserta didik yang lebih bermartabat.

c. Penyaring: untuk menyaring budaya bangsa sendiri dan budaya bangsa lain yang tidak sesuai dengan nilai-nilai budaya dan karakter bangsa yang bermartabat. ${ }^{50}$

\section{Tujuan Pendidikan Budaya Dan Karakter Bangsa}

a. Mengembangkan potensi kalbu/nurani/afektif peserta didik sebagai manusia dan warganegara yang memiliki nilai-nilai budaya dan karakter bangsa.

b. Mengembangkan kebiasaan dan perilaku peserta didik yang terpuji dan sejalan dengan nilai-nilai universal dan tradisi budaya bangsa yang religious.

c. Menanamkan jiwa kepemimpinan dan tanggung jawab peserta didik sebagai generasi penerus bangsa.

d. Mengembangkan kemampuan peserta didik menjadi manusia yang mandiri, kreatif, berwawasan kebangsaan.

e. Mengembangkan lingkungan kehidupan sekolah sebagai lingkungan belajar yang aman, jujur, penuh kreativitas dan persahabatan, serta dengan rasa kebangsaan yang tinggi dan penuh kekuatan (dignity). ${ }^{51}$

\section{Nilai-nilai dalam Pendidikan Budaya dan Karakter Bangsa}

Pendidikan tanpa identifikasi karakter hanya akan menjadi sebuah perjalanan tanpa arah, petualangan tanpa tujuan. Kita harus mampu mengidentifikasi karakter dasar yang

\footnotetext{
${ }^{49}$ Irhamni, Pengembangan Pendidikan Budaya dan Karakter Bangsa, 3

${ }^{50}$ Kementerian Pendidikan Nasional, Pengembangan Pendidikan Budaya dan Karakter bangsa (Jakarta: Badan Penelitian dan Pengembangan Pusat Kurikulum, 2010), 7

${ }^{51}$ Ibid, 7
} 
akan menjadi pilar perilaku manusia. Nilai-nilai yang dikembangkan dalam pendidikan budaya dan karakter bangsa diidentifikasi dari sumber-sumber berikut ini.

\section{a. Agama}

Masyarakat Indonesia adalah masyarakat beragama. Oleh karena itu, kehidupan individu, masyarakat, dan bangsa selalu didasari pada ajaran agama dan kepercayaannya. Secara politis, kehidupan kenegaraan pun didasari pada nilai-nilai yang berasal dari agama. Atas dasar pertimbangan itu, maka nilai-nilai pendidikan budaya dan karakter bangsa harus didasarkan pada nilai-nilai dan kaidah yang berasal dari agama.

\section{b. Pancasila}

Negara kesatuan Republik Indonesia ditegakkan atas prinsip-prinsip kehidupan kebangsaan dan kenegaraan yang disebut Pancasila. Pancasila terdapat pada Pembukaan UUD 1945 dan dijabarkan lebih lanjut dalam pasal-pasal yang terdapat dalam UUD 1945. Artinya, nilai-nilai yang terkandung dalam Pancasila menjadi nilai-nilai yang mengatur kehidupan politik, hukum, ekonomi, kemasyarakatan, budaya, dan seni. Pendidikan budaya dan karakter bangsa bertujuan mempersiapkan peserta didik menjadi warga negara yang lebih baik, yaitu warga negara yang memiliki kemampuan, kemauan, dan menerapkan nilai-nilai Pancasila dalam kehidupannya sebagai warga negara.

\section{c. Budaya}

Sebagai suatu kebenaran bahwa tidak ada manusia yang hidup bermasyarakat yang tidak didasari oleh nilai-nilai budaya yang diakui masyarakat itu. Nilai-nilai budaya itu dijadikan dasar dalam pemberian makna terhadap suatu konsep dan arti dalam komunikasi antar anggota masyarakat itu. Posisi budaya yang demikian penting dalam kehidupan masyarakat mengharuskan budaya menjadi sumber nilai dalam pendidikan budaya dan karakter bangsa.

\section{d. Tujuan Pendidikan Nasional}

Sebagai rumusan kualitas yang harus dimiliki setiap warga negara Indonesia, dikembangkan oleh berbagai satuan pendidikan di berbagai jenjang dan jalur. Tujuan pendidikan nasional memuat berbagai nilai kemanusiaan yang harus dimiliki warga negara Indonesia. Oleh karena itu, tujuan pendidikan nasional adalah sumber yang paling operasional dalam pengembangan pendidikan budaya dan karakter bangsa.budaya tertentu, maka pengembangan karakter individu seseorang hanya dapat dilakukan dalam lingkungan sosial dan budaya yang bersangkutan.

Bangsa adalah sekelompok manusia yang mau bersatu, merasa dirinya bersatu, memiliki kesamaan nasib, asal keturunan, bahasa, adat, sejarah bangsa akan jika disertai pemerintahan sendiri. Karakter Bangsa adalah keseluruhan sifat suatu bangsa yang 
mencakup perilaku, kebiasaan, kesukaan, kemampuan, bakat, potensi, nilai-nilai, dan pola pikir yang dimiliki oleh bangsa tersebut. ${ }^{52}$

\section{Kesimpulan}

Hasil dari penelitian ini, dapat ditarik beberapa kesimpulan sebagai berikut: Nilai-nilai pendidikan karakter dalam kesenian Reyog Ponorogo ditinjau dari makna-makna simbolnya yaitu:

Religius di antaranya: Reyog diambil dari bahasa Arab (Riyyuq) karena pengaruh bahasa Jawa maka berubah menjadi kata reyog yang artinya khusnul khotimah atau bagus pada akhirnya (apik pungkasane dalam bahasa Jawa). Warok yang dinisbatkan pada kata Wira'i, kolor/usus Warok yang berarti Ushushun artinya tali atau ikatan, yang menunjukan pada manusia untuk selalu berpegang pada tali Allah Swt. Pecut samandiman merupakan senjata yang digunakan Prabu Kelono Sewandono yang digunakan untuk menaklukan Singo Barong. Singo Barong diibaratkan kejelakan (hawa nafsu), saman artinya ono (ada), diman artinya iman. Tasbih atau mote yang dipasang pada Dhadhak Merak merupakan simbol atau identitas Islam. Pemaknaan terhadap gamelan Reyog yang selalu mengingatkan manusia pada sang Pencipta. Gong bermakna agung, yang artinya adalah mengagungkan Allah Swt. Kenong berbunyi "neng nong neng nong" bermakna "Qona'a” berarti menerima dengan ikhlas. Sedangkan kethuk bermakna khotho' yang berarti manusia tempat salah dan lupa, dari itu manusia dituntut untuk selalu mawas diri dalam menjalani kehidupan. Terompet maknanya adalah sebuah seruan, karena manusia harus selalu mendengarkan seruan Tuhan. Bunyi kendang adalah "ndang, ndang, ndang" yang artinya cepat-cepatlah, bersegeralah menjalankan perintah-Nya. Ketipung sering dinisbatkan dengan bahasa Arab Katifun, bermakna balasan, balas memabalas, jika seseorang mendapat kejahatan dari seseorang, maka tidak boleh membalas dengan kejahatan pula. Angklung bermakna perpindahan atau hijrah, yaitu perpindahan dari keburukan menjadi kebaikan.

Toleransi, di antaranya: Baju wakhtung berasal dari kata krowak dan buthung (berlubang dan putus sebagian). Cara memakainya buah baju tidak dikancingkan (terbuka), sehingga adanya sifat keterbukaan (toleransi) pada diri seorang warok. Dhadhak merak terdiri dari barongan/singa yang menyeramkan bersanding dengan merak yang penuh kelembutan. Hal ini menyiratkan pesan bahwa segala perbedaan jika disikapi dengan rasa toleransi akan berjalan baik. Gamelan Reyog yang berlaras pelog dan slendro menggambarkan perbedaan yang bisa berjalan penuh harmoni dan beriringan dengan baik.

${ }^{52}$ Ibid, 7 
Disiplin dan Kerja keras, di antaranya: Kisah tokoh Kelono Sewandono dan patihnya Pujangganong yang memiliki semangat disiplin dan kerja keras dalam menjalankan roda pemerintahan Kerajaan Bantarangin. Dari kisah yang melegenda saat Kelono Sewandono dibantu Patihnya mengambil hati Dewi Songgolangit juga merupakan sisi lain dari perilaku disiplin dan kerja keras mereka. Dalam kisah lain Bathoro Katong yang bekerja keras dalam menyebarkan agama Islam di tanah Wengker sampai harus berperang dengan Ki Ageng Kutu, adalah teladan bahwa dengan disiplin dan kerja keras bisa mewujudkan cita-cita yang diimpikan. Dalam setiap pementasan Reyog ditampilkan tokoh-tokoh seperti warok, jathilan, pujangganong, kelono sewandono, dhadhak merak yang membawakan tarian yang penuh karakter disiplin dan kerja keras dalam mencapai tujuan masing-masing. Pengrawit yang memainkan gamelan juga menunjukan hal yang sama. Tanpa didasari semangat disiplin dan kerja keras seluruh pementasan Reyog tindak akan berjalan baik.

Semangat Kebangsaan dan Cinta Tanah Air, di antaranya: Generasi penerus kesenian tradisional layaknya kesenian Reyog menjadi simbol orang-orang yang memiliki semangat kebangsaan dan cinta tanah air yang tinggi. Tokoh-tokoh yang muncul dalam kesenian Reyog, seperti barongan atau dhadak merak, kelono sewandono, pujangganong, jathilan adalah sosoksosok yang memiliki semangat kebangsaan dan cinta tanah air. Dalam cerita pementasan Reyog walaupun ceritanya kubu Kelono Sewandono berperang melawan Singo Barong yang memperebutkan Dewi Songgolangit, di sisi lain mereka berperang atas nama harga diri, semangat kebangsaaan, dan cinta tanah air. Dalam hal ini kerajaan sebagai tanah air yang mereka bela. Warok, Pujangganong, Jathilan yang selalu bersikap dan bertindak setia pada kerajaan dan Raja dalam pementasan Reyog menunjukan simbol cinta tanah air yang tinggi.

Nilai-nilai pendidikan karakter dalam kesenian Reyog Ponorogo ditinjau dari maknamakna simbolnya yaitu: Religius, Toleransi, Disiplin dan Kerja keras, Kreatif, Semangat Kebangsaan dan Cinta Tanah Air, Tanggung Jawab sangat relevan dengan tujuan pendidikan Islam. 


\section{DAFTAR PUSTAKA}

Ahmad. Implementasi Akhlak Qur'ani. Bandung : PT Telekomunikasi Indonesia. 2002.

Ainusysyam, Fadlil Yuni. Pendidikan Akhlak. Jakarta: PT Imtima. Cet. III. 2009.

Arifin, H. M. Filsafat Pendidikan Islam. Jakarta: Bumi Aksara. 1987.

Arismantoro. Tinjauan Berbagai Aspek "Character Building” Bagaimana Mendidik Anak Berkarakter. Yogyakarta: Tiara Wacana. 2008.

Athiyyatillah. Nilai-nilai Pendidikan Islam dalam Ibadah Solat. skripsi, Fakultas Tarbiyah.

UIN Malang. 2009.

Depag RI. al-Qur'an dan Terjemahannya. Semarang: Asy Syifa'. 1998.

Effendi, Mukhlison. Ilmu Pendidikan. Ponorogo: STAIN Ponorogo Press. 2008

Hasbullah. Dasar-Dasar Ilmu Pendidikan. Jakarta: Raja Grafindo Persada. 1999.

Hawwa, Said. Tazkiyatun Nafs Intisari Ihya Ulumuddin (terj. Tim Kuwais). Jakarta : Darus

Salam. 2005. Hidayatullah, M. Furqon. Pendidikan Karakter Membangun Peradaban

Bangsa. Surakarta: Yuma Pressindo. 2010.

http://id.wikipedia.org/wiki/Reyog_\%28Ponorogo\%29, Diakses, 5 januari 2014.

http://id.wikipedia.org/wiki/Seni, diakses 15 juli 2014.

Irhamni. Pengembangan Pendidikan Budaya Dan Karakter Bangsa. Ponorogo: Depag

Ponorogo. 2011.

Jalaludin. Teologi Pendidikan.cet III. Jakarta: PT Raja Grafindo Persada. 2003.

Khan, Yahya. Pendidikan Karakter Berbasis Potensi Diri, Mendongkrak Kualitas

Pendidikan. Yogyakarta: Pelangi Publishing. 2010.

Koesoema A, Doni. Pendidikan Karakter, Strategi Mendidik Anak Di Zaman Global. Jakarta:

Grasindo. 2007.

Maryani. Metode Penelitian Kebudayaan. Jakarta: Bumi Aksara. 2005.

Mudyaharjo, Redja. Pengantar Pendidikan Sebuah Studi Awal Tentang Dasar-dasar

Pendidikan Pada Umumnya Dan Pendidikan Di Indonesia. Jakarta: Raja Grafindo

Persada. 2001.

Muhadjir, Noeng. Ilmu Pendidikan dan Perubahan Sosial. Yogyakarta: Rake Sarasin. 2000.

Mulyana, Rohmat. Mengartikulasikan Pendidikan Islam. Bandung: IKAPI. 2004.

Nata, Abuddin. Pemikiran Para Tokoh Pendidikan Islam. Jakarta: PT Raja Grafindo Persada. 2000.

Pemerintah Kabupaten Daerah Tingkat II Ponorogo. Pedoman Dasar Kesenian Reog Ponorogo Dalam Pentas Budaya Bangsa. Ponorogo: PEMKAB Ponorogo. 1996. 
Purwadarminta, W.JS. Kamus Umum Bahasa Indonesia. Jakarta: Balai Pustaka. 1999.

Ramayulis. Ilmu Pendidikan Islam cet VII. Jakarta: Kalam Mulia. 2002.

Rusn, Abidin Ibnu. Pemikiran Al-Ghazali tentang Pendidikan.Yogyakarta: Pustaka Pelajar. 1998.

Setiadi, Elly M. Ilmu Sosial dan Budaya Dasar. Jakarta: Kencana. 2006.

Sulhan, Najib. Pendidikan Berbasis Karakter,Sinergi Antara Sekolah dan Rumah dalam Membentuk Karakter Anak. Surabaya: Jepe Press. 2010.

Thoha, Chabib. Kapita Selekta Pendidikan Islam. Yogyakarta: Pustaka Pelajar. 1996.

Ulwan, Abdullah Nashih. Pedoman Pendidikan Anak dalam Islam. Semarang: CV Asyifa. 1988.

Wahyu, Ramdani. Ilmu Budaya Dasar. Bandung: Pustaka Setia. 2008. 